\title{
(5)

\section{En alvorlig deprimert kvinne med uvanlig respons på antidepressiver}

NOE Å LAERE AV

\section{NINA SUNDFJORD}

E-post: ninasundfjord@gmail.com

Medisinsk avdeling

Voss sjukehus

Haukeland universitetssykehus

Hun har bidratt med litteratursøk, skriving av kommentarer, utarbeiding av manuskriptet og godkjent innsendt versjon.

Nina Sundfjord (f. 1989) er lege i spesialisering i indremedisin.

Forfatter har fylt ut ICMJE-skjemaet og oppgir ingen interessekonflikter.

\section{GIA THANH TRAN}

Sjukehusapoteket i Bergen

og

Institutt for global helse og samfunnsmedisin

Universitetet i Bergen

Hun har bidratt med litteratursøk, skriving av kommentarer, utarbeiding av manuskriptet og godkjent innsendt versjon.

Gia Thanh Tran (f. 1988) er sykehusfarmasøyt og universitetslektor.

Forfatter har fylt ut ICMJE-skjemaet og oppgir ingen interessekonflikter.

\section{BRIT HAVER}

Universitetet i Bergen

og

Avdeling for affektive lidelser

Psykiatrisk klinikk

Haukeland universitetssykehus

Hun hadde ideen til kasuistikken og har bidratt i utarbeiding av manuskriptet og godkjent innsendt versjon.

Brit Haver (f. 1942) er professor emeritus og overlege.

Forfatter har fylt ut ICMJE-skjemaet og oppgir ingen interessekonflikter.

En kvinne i 4o-årene ble innlagt i psykiatrisk avdeling etter et selvmordsfors $ø$ k. Tilstanden ble vurdert som en melankoliform depresjon med vrangforestillinger. Antidepressiver hadde ikke ønsket effekt. Genetiske tester ga viktig informasjon om videre behandling.

En kvinne som aldri tidligere hadde vært behandlet innen psykisk helsevern, ble innlagt etter et alvorlig selvmordsfors $\emptyset$ k. Hun hadde kuttet seg i begge håndledd. Pasienten ble innlagt i plastikkirurgisk avdeling for sutur av sårskadene og deretter overført til psykiatrisk klinikk.

Pasienten fortalte at hun hadde følt seg trist det siste halvåret. Hun var plaget av konsentrasjons- og hukommelsesvansker, dårlig matlyst og en følelse av håpløshet. Hun 
hadde ikke kunnet glede seg over et barnebarn som var født få dager før innleggelsen. I tillegg hadde hun betydelige søvnvansker og kunne sove så lite som to timer per natt. Hun følte at hun ikke strakk til, verken hjemme eller på arbeid. I en periode hadde hun forsøkt å trene seg frisk, men måtte oppgi dette, da hun ikke hadde energi. Hun mente at hun var en belastning for familien, maktet ikke å gå på butikken og isolerte seg i hjemmet.

Selvmordstankene kom samme dag som hun utførte selvskadingen. Hun hadde da hatt en telefonsamtale med Nav. Hun forsto lite av samtalen og kunne ikke huske hva som var blitt sagt etterpå. Hun følte seg bare ytterligere fortvilet.

Pasienten hadde gjennom hele sitt voksne liv hatt perioder med depressive symptomer, men vegret seg for å involvere spesialisthelsetjenesten. Det eneste antidepressive medikamentet hun tidligere hadde tålt, var escitalopram - et medikament av typen selektive serotoninreopptakshemmere (SSRI) som hun hadde brukt gjennom flere år, omkring ti år tilbake, med effekt.

Forut for den aktuelle innleggelsen hadde pasienten vært sykmeldt et halvt år grunnet depressive symptomer. Fastlegen hadde i denne perioden gitt henne flere antidepressiver. Disse medikamentene sluttet hun å ta i løpet av få dager grunnet bivirkninger. Av vortioksetin fikk hun magesmerter, nedsatt hukommelse, talevansker og mulige hallusinasjoner, som er kjente bivirkninger. Medikamentet angis å ha en multimodal virkningsmekanisme med en kompleks innvirkning på flere serotonerge reseptorer. I tillegg hemmer det serotonintransportøren. Under behandling med mianserin utviklet hun hudutslett som antas å være allergisk betinget. Dette er et antidepressivum av piperazin-azepin-gruppen. Citalopram, som er klassifisert som en selektiv serotoninreopptakshemmer, ga kramper i kjevemuskulaturen eller skjæring av tennene, noe som er kjente bivirkninger av selektive serotoninreopptakshemmere. Doseringen av medikamentene var ikke kjent. Hun hadde få dager før selvmordsforsøket startet opp med en lav dose mirtazapin, en reseptorantagonist som utøver antidepressiv virkning ved å blokkere de hemmende presynaptiske alfa-2-reseptorene.

Mens hun var innlagt i psykiatrisk klinikk forverret tilstanden seg. Hun formidlet tanker om at Nav mistenkte henne for trygdemisbruk og skulle «ta» henne og familien fordi hun ikke fungerte i et yrke hun tidligere var rehabilitert til. Hun viste liten innsikt i egen sykdomssituasjon og mente det beste for henne var å bli utskrevet.

Tilstanden ble etter hvert oppfattet som en alvorlig depressiv episode av typen melankoli, med stemningskongruente vrangforestillinger. Hun benektet selvmordstanker eller planer, men anga sterk indre uro og redsel.

Hun ble nå anbefalt elektrokonvulsiv terapi (ECT) som anses mest effektiv ved denne typen depresjon, men hun nektet å gjennomføre dette. Da pasienten allerede var medisinert med mirtazapin 7,5 mg uten å oppleve bivirkninger, ble dosen gradvis økt til $45 \mathrm{mg}$ kveld med tillegg av escitalopram $5 \mathrm{mg}$, som gradvis ble økt til $15 \mathrm{mg}$ daglig. Hun fikk dessuten antipsykotisk medikasjon i form av aripiprazol, som senere ble erstattet av olanzapin $10 \mathrm{mg}$ om kvelden grunnet vrangforestillingene, uroen og søvnproblemene.

Differensialdiagnostisk ble hun henvist til utredning med tanke på epileptogen eller hjerneorganisk årsak til symptombildet. MR caput viste en liten cyste i relasjon til corpus pineale, sannsynligvis uten klinisk betydning. Resultatet av EEG-undersøkelse var normalt. Nevrologisk undersøkelse ga ikke holdepunkt for nevrologisk betinget sykdom. Ved innleggelsen i plastikkirurgisk avdeling hadde pasienten høyt blodsukker, og hun hadde vært hypertensiv i månedene før innleggelsen. Hormonanalyser, stoffskifte- og vitaminverdier viste ikke tegn til endokrine forstyrrelser som kunne forklare symptombildet.

På den angitte medikasjonen bedret søvnen seg betraktelig, mens de depressive vrangforestillingene tiltok. Fem uker inn i oppholdet utviklet pasienten tanker om at hun «luktet så ille at medpasienter og personale på avdelingen kastet opp av den forferdelige stanken». Etter hvert klaget hun også over forstoppelse. Hun sluttet nesten å spise og drikke, 
da hun mente at tarmene manglet passasje. Somatisk undersøkelse viste vekttap, men ingen kliniske tegn til obstipasjon. Hun utviklet $ø$ kende motorisk uro med stepping. Man mistenkte utvikling av ekstrapyramidale bivirkninger, muligens knyttet til olanzapin, og det ble lagt til et antikolinergikum med sentralnervøs effekt, biperidenhydroklorid, uten observerbar effekt. På grunn av økende uro og forverring i den depressive tilstanden ble escitalopram gradvis seponert. Steppingen forsvant, men de depressive vrangforestillingene vedvarte og var ukorrigerbare.

Da pasienten ikke responderte som forventet på de antidepressive medikamentene, og $\mathrm{i}$ tillegg hadde utviklet bivirkninger av flere medikamenter før innleggelsen, ble det rekvirert cytokrom-P450 (CYP)-genotyping og måling av serumkonsentrasjoner av de aktuelle legemidlene. Serumkonsentrasjonsmålingene viste verdier innen referanseområdene: escitalopram (15 mg/døgn) $38 \mathrm{nmol} / \mathrm{l}$ (referansenivå 20-120 nmol/l) og mirtazapin (45 mg/døgn) $62 \mathrm{nmol} / \mathrm{l}$ (referansenivå 50-113 nmol/l). Det ble også rekvirert gentesting av serotonintransportøren, som sammen med tidligere rekvirerte CYP-tester utgjorde et serotoninpanel. Svar på genetisk testing viste en genvariant som medførte tap av enzymaktivitet via $\mathrm{CYP}_{2} \mathrm{C}_{9}$ og CYP2D6, i tillegg til at pasienten hadde to korte allelvarianter av genet som koder for serotonintransportøren.

Da pasienten hadde vært innlagt i psykiatrisk klinikk i nesten to måneder og ikke viste tegn til klinisk bedring, ble alternativet med elektrokonvulsiv terapi på nytt anbefalt. Hun samtykket da til behandlingen, og fikk i alt ni behandlinger med høyresidig unilateral elektrodeplassering.

Allerede etter første behandling med elektrokonvulsiv terapi inntrådte en forbigående, nærmest total remisjon. Etter syv behandlinger ble hun oppfattet å være i nøytralt stemningsleie uten vrangforestillinger. Hun hadde ingen symptomer og rapporterte ingen bivirkninger av behandlingen. Hun fikk to nedtrappingsbehandlinger og ble utskrevet til langvarig poliklinisk oppfølging ved et distriktspsykiatrisk senter (DPS) med mirtazapin $45 \mathrm{mg}$ og olanzapin $5 \mathrm{mg}$ som vedlikeholdsmedikasjon.

\section{Diskusjon}

Det har lenge vært kjent at genetisk variasjon i cytokrom-P450 (CYP)-systemet kan påvirke behandling med psykofarmaka. CYP-systemet er en enzymfamilie som metaboliserer legemidler i kroppen slik at de lettere elimineres. Selektive serotoninreopptakshemmere omsettes av blant annet CYP2D6 og CYP2C19. Både CYP2D6 og CYP2 19 forekommer i genetiske varianter som medfører endret aktivitet av cytokromet. Ved redusert aktivitet $\emptyset$ ker risikoen for bivirkninger, og ved økt aktivitet kan effekten av selektive serotoninreopptakshemmere bortfalle (1).

En annen kjent polymorfisme, som kan påvirke effekten av selektive serotoninreopptakshemmere, er varianter i genet som koder for serotonintransportøren. Selektive serotoninreopptakshemmere utøver sin effekt ved å hemme en serotonintransportør kodet av genet SLC6A4. En mulig forklaring på effektvariasjonen av selektive serotoninreopptakshemmere finner man i et repeterende område i genet som finnes i en lang og en kort variant (2). Omtrent $22 \%$ av kaukasiske personer har to alleler av den korte varianten. Dette medfører en $ø$ kt risiko for bivirkninger som agitasjon, insomni og gastrointestinale plager, i tillegg til manglende effekt av medikamentene. Det er ikke en risiko hos personer med to lange eller én lang og én kort allelvariant (2-6). For pasienter med to alleler av den korte varianten bør det vurderes annen behandling enn selektive serotoninreopptakshemmere, for eksempel en reseptorantagonist som mirtazapin (7).

De bivirkningene som pasienten rapporterte på de ulike antidepressivene, kan imidlertid tenkes å være uten sammenheng med de påviste genvariasjonene. Ved måling av serumspeilet lå pasientens verdier innenfor referanseområdet, til tross for de påviste genvariantene i CYP-enzymene som medførte tap av enzymaktivitet via CYP2 9 og CYP2D6. Det er dessuten meget vanlig at pasienter initialt klager over bivirkninger ved bruk av 
antidepressiver. En medvirkende faktor kan være for høy startdose, eller at pasienter under en depresjon er særlig sensitive for ethvert symptom som kan oppfattes som en forverring av tilstanden. Dette fører ofte til prematur seponering av medikamenter som kunne ha vist seg å være effektive og uten bivirkninger på sikt. Derfor er forsiktig, fortsatt dosering over flere uker indisert for å se om bivirkningene avtar og den forventede effekten inntrer. Hos vår pasient kom det imidlertid ingen bedring.

Den manglende effekten av de antidepressive medikamentene kan på den annen side skyldes selve tilstandsbildet som pasienten viste, nemlig en melankoliform depresjon med vrangforestillinger. Melankoliforme depresjoner kjennetegnes av markert anhedoni (manglende lystfølelse) og psykomotoriske endringer i form av agitasjon eller retardasjon. I tillegg ses utpregede kognitive forstyrrelser med nedsatt evne til å oppfatte og lagre ny informasjon, videre nedsatt matlyst med vekttap og skyldfølelse, som kan ta form av vrangforestillinger om å ha gjort noe galt. Betydelige søvnforstyrrelser med tidlig oppvåkning er også en del av tilstandsbildet. Det kan eventuelt være døgnvariasjoner i stemningsleiet, med heving av stemningsleiet mot kvelden, noe vår pasient ikke viste.

Nyere forskning tyder på at melankoliforme depresjoner har særlige biologiske kjennetegn som skiller dem fra andre alvorlige depresjoner (8). Dette viser seg blant annet i form av høy heritabilitet, lav respons på placebo, markert effekt av «gammeldagse» trisykliske antidepressiver (TCA) og monoaminoksidasehemmere (MAOH), mens selektive serotoninreopptakshemmere har liten effekt (8).

Forverringen i tilstanden som ble observert under den aktuelle innleggelsen, kan følgelig skyldes at grunnlidelsen ikke lar seg behandle med selektive serotoninreopptakshemmere. Hvilken innvirkning de genetiske avvikene kan ha hatt, er ikke mulig å si.

Depresjon er en vanlig lidelse, med en nær dobbelt så høy prevalens hos kvinner sammenlignet med menn $(9,10)$. I en studie fra Oslo ble det beregnet at livstidsprevalensen for en alvorlig depressiv lidelse er $24 \%$ blant kvinner (9).

Vår pasient oppfylte kriteriene for en melankoliform depresjon med depressive vrangforestillinger, som er en betydelig sjeldnere tilstand. Studier har vist at $14-16 \%$ utvikler en ny depressiv episode allerede seks måneder etter avsluttet behandling for depresjon, mens rundt $25 \%$ får tilbakefall i løpet av det neste året $(11,12)$. Dette gjelder pasienter som har oppnådd symptomfrihet - sannsynligheten for tilbakefall er signifikant høyere dersom det består restsymptomer (11). Grunnet risikoen for tilbakefall er det avgjørende at pasienten blir fulgt opp over lang tid, og at man tilstreber å oppnå remisjon av enhver depressiv episode. Vår pasient ble utskrevet til langvarig poliklinisk oppfølging med mirtazapin og olanzapin som vedlikeholdsbehandling.

Denne historien viser at dersom en pasient utvikler bivirkninger, mer enn $\emptyset$ nsket bedring, av en rekke antidepressive legemidler, er det hensiktsmessig å rekvirere både CYPgenotyping og genetisk testing av serotonintransportøren. Til sammen utgjør disse et fullt SSRI-panel. Et slikt panel kan gi informasjon om hvilke medikamenter som har effekt, og hvilke man skal velge i fremtidig behandling.

For vår pasient var det informasjonen fra de farmakogenetiske analysene som medførte at det ble anbefalt at hun ikke ble behandlet med selektive serotoninreopptakshemmere ved en eventuell senere depresjon, men heller med reseptorantagonister slik som mirtazapin. Hennes opplysninger om at hun tidligere hadde tålt selektive serotoninreopptakshemmere i form av escitalopram kan antagelig forklares av at tilstanden den gang ikke var så alvorlig og at dosen var lav.

1. Rudberg I. Betydning av CYP2C19-genetikk for SSRI-preparater. Nor Farm Tidsskr 2010; 6: 24 - 5 . 2. Hu X-Z, Rush AJ, Charney D et al. Association between a functional serotonin transporter promoter 
polymorphism and citalopram treatment in adult outpatients with major depression. Arch Gen Psychiatry 2007; 64: 783 - 92. [PubMed][CrossRef]

3. Perlis RH, Mischoulon D, Smoller JW et al. Serotonin transporter polymorphisms and adverse effects with fluoxetine treatment. Biol Psychiatry 2003; 54: 879 - 83. [PubMed][CrossRef]

4. Staeker J, Leucht S, Laika B et al. Polymorphisms in serotonergic pathways influence the outcome of antidepressant therapy in psychiatric inpatients. Genet Test Mol Biomarkers 2014; 18: 20 - 31.

[PubMed][CrossRef]

5. Garfield LD, Dixon D, Nowotny P et al. Common selective serotonin reuptake inhibitor side effects in older adults associated with genetic polymorphisms in the serotonin transporter and receptors: data from a randomized controlled trial. Am J Geriatr Psychiatry 2014; 22: 971 - 9. [PubMed][CrossRef]

6. Iurescia S, Seripa D, Rinaldi M. Role of the 5 -HTTLPR and SNP promoter polymorphisms on serotonin transporter gene expression: a closer look at genetic architecture and in vitro functional studies of common and uncommon allelic variants. Mol Neurobiol 2016; 53:5510 - 26.

[PubMed][CrossRef]

7. Murphy GM, Hollander SB, Rodrigues HE et al. Effects of the serotonin transporter gene promoter polymorphism on mirtazapine and paroxetine efficacy and adverse events in geriatric major depression. Arch Gen Psychiatry 2004; 61: 1163 - 9. [PubMed][CrossRef]

8. Parker G, Bassett D, Outhred T et al. Defining melancholia: A core mood disorder. Bipolar Disord 2017; 19: 235 - 7. [PubMed][CrossRef]

9. Kringlen E, Torgersen S, Cramer V. A Norwegian psychiatric epidemiological study. Am J Psychiatry 2001; 158: 1091 - 8. [PubMed][CrossRef]

10. Kringlen E, Torgersen S, Cramer V. Mental illness in a rural area: a Norwegian psychiatric epidemiological study. Soc Psychiatry Psychiatr Epidemiol 2006; 41: 713 - 9. [PubMed][CrossRef]

11. Judd LL, Schettler PJ, Rush AJ et al. A new empirical definition of major depressive episode recovery and its positive impact on future course of illness. J Clin Psychiatry 2016; 77: 1065-73. [PubMed][CrossRef]

12. Judd LL, Schettler PJ, Rush AJ. A brief clinical tool to estimate individual patients' risk of depressive relapse following remission: proof of concept. Am J Psychiatry 2016; 173: 1140 - 6. [PubMed][CrossRef]

Publisert: 13. april 2018. Tidsskr Nor Legeforen. DOI:10.4045/tidsskr.16.1134

Mottatt 21.12.2016, første revisjon innsendt 14.3.2017, godkjent 12.2.2018.

(C) Tidsskrift for Den norske legeforening 2020. Lastet ned fra tidsskriftet.no 